DOI: $10.26693 /$ jmbs05.06.252

UDC 616.216.1-002.3-073.756.8

Pohodenko-Chudakova I. O., Maksimovich E. V., Hosseinpour A. M.

\title{
THE MAXILLARY ARTERY DEFINITION ACCORDING TO CBCT DATA IN PATIENTS WITH CHRONIC MAXILLARY SINUSITIS
}

\author{
Belarusian State Medical University, Minsk, Republic of Belarus
}

ip-c@yandex.ru

The number of maxillary sinusitis is significant in the structure of inflammatory diseases in an outpatient maxilla-facial surgery and they are one of the chief reasons for the patients' hospitalization. The anatomy of maxillary sinus with 3D Computer tomography scan should be included in appropriate presurgical treatment planning.

The purpose of the study was to determine the visualization and diameter of the maxillary artery in according analyzing of Cone bean computer tomography data of patients, to identify the relationship between the presence of chronic maxillary sinusitis and the visualization of the maxillary artery and its diameter.

Material and methods. The data of 44 Cone bean computer tomography results was analyzed for 24 patients with chronic maxillary sinusitis of odontogenic origin (it was observation group 1, included 48 sinuses), 20 patients were without pathological changes in the maxillary sinus (it was comparison group 2, included 40 sinuses). All the Cone bean computer tomographies randomly selected by patients who visited dental outpatient clinics of Minsk city, the Republic of Belarus during the period from 2018 to 2020 and were analyzed by GALILEOS program.

Results and discussion. The analysis revealed that maxillary artery was not detected in $25.0 \%$ (12) patients of group 1, while in group 2 it was not detected in $5.0 \%$ (2) patients. When determining the diameter of the maxillary artery, we found that in group 1 patients, the artery diameter $0.1-0.99 \mathrm{~mm}$ was determined in $91.7 \%$ (33) cases, and in $92.2 \%$ (35) of group 2 patients; the diameter of the maxillary artery $1.0 \mathrm{~mm}$ or more in group 1 patients was determined in $8.3 \%$ (3) of observations, and in $7.8 \%$ (3) of group 2 patients Different types of the maxillary arteries localization were revealed.

Conclusion. The study results showed that in patients of group 1 with the presence of chronic maxillary sinusitis, the maxillary artery was not visualized 5 times more often than in patients of group 2 (comparison group), which may indicate to deeper ischemic changes in the maxillary tissues of patients with chronic maxillary sinusitis. There was no significant difference in the diameter of the maxillary arteries in groups 1 and 2 . The study will be continued.
Keywords: Cone bean computer tomography, maxillary artery, chronic maxillary sinusitis.

Introduction. The maxillary sinuses are the largest from the paranasal. As it's known from the anatomy the vascular system of the maxillary sinus varies in architecture and vascular anastomosis of the vessels [1]. The three branches of the maxillary artery the posterior superior alveolar, infraorbital, posterior lateral nasal arteries supply the maxillary sinus. The maxillary artery emanates from the external carotid artery. It should be taken into account that the network that is formed from the ramifications of these arteries located in and below the mucous membrane lining of the nasal cavity and sinuses and intraosseously (Dennis Flanagan, 2006). And these arteries should be taken into account during planning any type of the maxillary surgery. This can cause complications with severe bleeding in surgical procedures that will need ligation of artery [1, 2].

Inflammation of the maxillary sinus - sinusitis is one of the most frequently diagnosed inflammatory diseases of the maxillofacial region. It should be noticed that since $5-15 \%$ of the adult, working-age population (18-55 years old) suffer from this disease, which makes this issue significant both socially and economically [3].

If an inflammatory condition of the maxillary sinuses is the result of dental pathology it is called odontogenic. The share of odontogenic lesions of the maxillary sinus (MS), according to dentists and maxillofacial surgeons, can reach $40 \%$, and according to otorhinolaryngologists - $13 \%$ of all diagnosed inflammatory lesions of the specified sinus. The frequency of maxillary sinusitis of odontogenic etiology varies from $2-6 \%$ to $24-50 \%$ of all diseases of the paranasal sinuses. At the same time, a significant part of all MS diseases is chronic sinusitis, which affects from $5 \%$ till $20 \%$ of the world's population. A large number of publications deal with the issues of research and search for new methods of treatment and diagnosis of chronic maxillary sinusitis $[4,5,6]$.

The basic factor of odontogenic lesion of the MS is the periapical inflammatory process in the area of the roots of the teeth, protruding or adjacent to the maxillary sinus. In a case of a tooth extraction opera- 
tion in such a condition, there is a high probability of the forming of an oroantral anastomosis after an operation. According to N. A. Cohen (2006), in 64.3\% of perforations of the MS occurs: due to an inflammatory process in the periapical tissues of the tooth root that protrudes into the space of the MS or to a pathological process with the sinus itself. According to scientific literature, the share of iatrogenic odontogenic lesions of the MS in the overall structure of its inflammatory pathology is $56-90 \%$. The number of odontogenic sinusitis caused by tooth extraction is up to $46 \%$ of cases from all the revealed facts of iatrogenic etiology of MS inflammation; $22 \%$ - a filling material brought out in the sinus cavity, intended for filling the root canals of teeth; $5 \%$ - the verified presence of amalgam in the sinus left after retrograde filling of the root canal during the operation of the root apex resection. In $10 \%$ of cases, the inflammatory process develops in the presence of a focus of chronic odontogenic infection, localized up to the sinus or inside it. The following factors related to iatrogenic and leading to the development of odontogenic sinusitis of the VSP should be considered: endodontic treatment without an apex locator and other measuring instruments and devices, using of endodontic instruments without limiting the immersion of the working part into the root canal, using of toxic materials and damaging concentrations of drugs during antiseptic instillation of root canals; violation of the technology of filling the root canal with filling material; lack of quality control of endodontic treatment using radiation research methods; incorrect determination of indications and technology for dental implantation; technical errors during sinus lifting operation. Each of the described clinical situations may be accompanied by perforation of the Schneider's membrane and the penetration of foreign bodies into the MS and formation of the oroantral fistula. The oroantral fistula (an active passage of the oral fluid) occurs with food particles and microflora in the upper junction, which leads to the development of a long-term inflammatory process in the damaged MS [6, 7].

Odontogenic maxillary sinusitis among surgical dental patients ranges from $4.2 \%$ to $8 \%$. According to the statistics, the odontogenic maxillary sinusitis in majority of cases doctors fix chronic forms occurs more than acute. The most common reasons for this are the later visit of the patient to the doctor; negligence of dentists in the early diagnosis of acute maxillary sinusitis in patients with acute and exacerbation of chronic periodontitis of the upper premolars and molars; difficulties in the diagnosis of odontogenic sinusitis. The reasons for this are: the clinical picture of periodontitis of the upper lateral teeth distorts the clinical picture of maxillary sinusitis; unqualified complex treatment of acute odontogenic sinusitis leads to complications and exacerbations of this disease; the lack of a comprehensive algorithm for treatment and prevention, the method of interaction of an interdisciplinary approach of a dentist and an otorhinolaryngologist for early diagnosis, treatment and prevention of odonotogenic sinusitis [5, 8].

The left and right maxillary sinuses are affected approximately equally often. Bilateral maxillary sinus involvement is rare. Odontogenic maxillary sinusitis in $18 \%$ of patients can be combined with inflammation of the ethmoid sinuses and in $2.5 \%$ of the frontal sinuses, therefore, it is not always isolated. This pathology takes an essential place in the practice of a dentistsurgeon both at an outpatient appointment and in an inpatient clinic. The information about the treatment methods of this pathology that is available in various scientific sources is not always clearly stated, sometimes it is contradictory. The predisposing factors for developing of odontogenic maxillary sinusitis are the anatomical and topographic proximity of the periapical tissues of the maxillary teeth (premolars and molars) to the maxillary sinus. Closest to the sinus is the first molar, less often the second molar and the second premolar, even less often the third molar and the first premolar. The anatomical relationship between the teeth and the MS depends on the size of the MS. In a case of a large MS, the roots of the teeth are closer to its bottom, and sometimes protrude into its space. The thickness of the bone plate separating the apexes of the roots from the space of the MS varies from 0.2 to $12 \mathrm{~mm}$. In a case of a wide and low upper jaw, the alveolar cavity of the sinus can extend to the level of the canine and even the second incisor [7, 9, 10].

And according etiology most often it's the result of maxillary dentition infections, dentoalveolar procedures, maxillary dental trauma. It should be noted that in majority of cases infections are often polymicrobial with an anaerobe-predominant microbiome [3, 4].

In accordance with the literature overview, the trials in development of optimal and diagnostic techniques, complex treatment, prevention of odontogenic maxillary sinusitis is a promising direction.

The purpose of the study was to determine the visualization and diameter of the maxillary artery in according analyzing of CBCT data of patients, to identify the relationship between the presence of chronic maxillary sinusitis and the visualization of the maxillary artery and its diameter.

Material and methods. The data of 44 CBCT results was analyzed where 24 patients had chronic maxillary sinusitis of odontogenic origin (it was observation group 1, included 48 sinuses), and 20 patients were without pathological changes in the maxillary sinus (it a was comparison group 2, which included 40 sinuses). All the CBCTs randomly selected by patients who visited dental outpatient clinics of Minsk city, the 
Republic of Belarus during the period from 2018 to 2020 and were analyzed by GALILEOS program.

The study was conducted in accordance with the basic bioethical norms of the Helsinki Declaration of the world medical Association on ethical principles for medical research amendments $(2000,2008)$, Universal Declaration on bioethics and human rights (1997), Convention of the Council of Europe on human rights and Biomedicine (1997). Written informed consent was obtained from all patients, and a full range of measures was taken to ensure their anonymity.

Results and discussion. The results analysis revealed that maxillary artery was not detected in $25.0 \%$ (12) patients of group 1 , while in group 2 it was not detected in $5.0 \%$ (2) patients (figure 1).

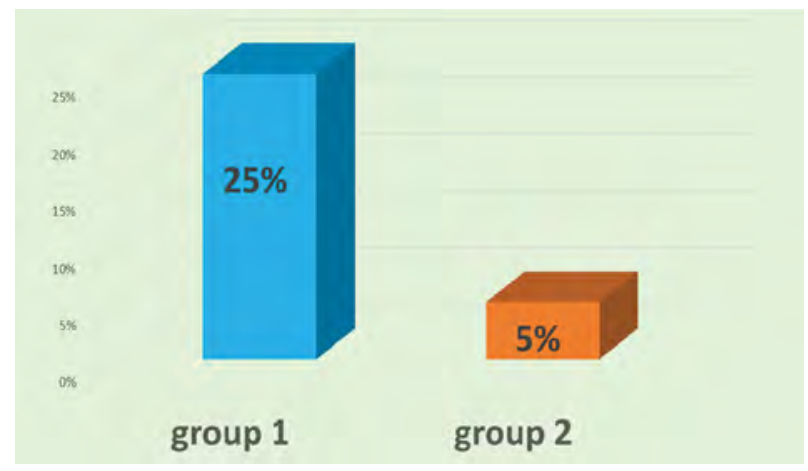

Fig. 1. The maxillary artery nonvisualization

When determining the diameter of the maxillary artery, we found that in group 1 patients, the artery diameter 0.1-0.99 $\mathrm{mm}$ was determined in $91.7 \%$ (33) cases, and in $92.2 \%$ (35) of group 2 patients; the diameter of the maxillary artery $1.0 \mathrm{~mm}$ or more in group 1 patients was determined in $8.3 \%$ (3) of observations, and in $7.8 \%$ (3) of group 2 patients (figure 2).

There were revealed different types of the maxillary arteries localization (figure $\mathbf{3}$ ).

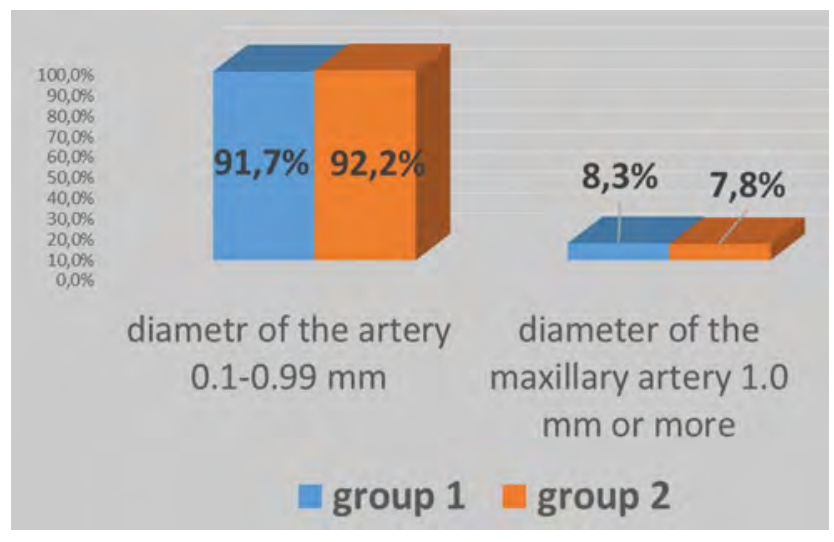

Fig. 2. Diameter of the maxillary artery in patients of groups 1,2

An essential diagnostic tool in the diagnosis and management of odontogenic sinusitis is radiographic imaging, include Periapical radiography and panoramic radiography are standard dental radiographs [11]. But it should be noted that they are limited in the evaluation of multi-rooted teeth that are most commonly the cause of odontogenic sinusitis. But it was written by scientists that the overall sensitivity of dental radiographs in the detection of periodontal disease and carious dental lesions are $85.0 \%$ and $60.0 \%$, respectively [12, 13]. And high rates of false negatives results were reported with one study demonstrating that compared to cone beam computerized tomography (CBCT) imaging periapical radiography missed more than $60 \%$ of periodontal pathology $[14,15]$.

According the literature data, the 3D-CT are able to identify the maxillary artery. Different types of localization of maxillary artery should be taken into account during maxillofacial surgery as well as in neurosurgery, for example in therapeutic techniques such as extracranial-intracranial (EC-IC) bypass, intracranial endonasal approaches and endovascular procedures [12]. And the diameter of the maxillary
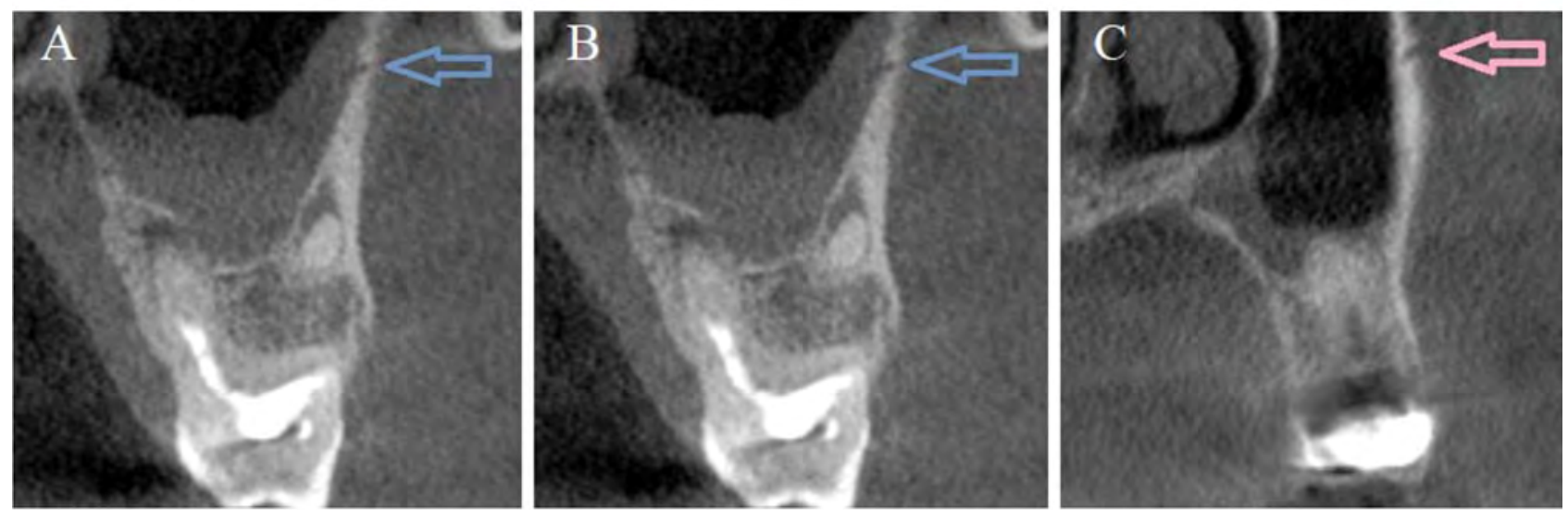

Fig. 3. A. The detection of the posterior superior alveolar artery, intraosseous localization. B. The detection of the posterior superior alveolar artery, localization under the sinus membrane (between the Schneiderian membrane and the lateral bony wall of the sinus, in which a small concavity was often visible). $\mathbf{C}$. The detection of the posterior superior alveolar artery, localization out of cortex (under the periosteum of the sinus lateral wall) 
artery can influence on the blood flow in mucosa of maxillary sinus. And in a case of lack of blood supply and nonvisible maxillary artery we can suspect ischemia of soft tissues and chronic inflammation.

Conclusion. The study results showed that in patients of group 1 with the presence of chronic maxillary sinusitis, the maxillary artery was not visualized 5 times more often than in patients of group 2 (comparison group), which may indicate to deeper ischemic changes in the maxillary tissues of patients with chronic maxillary sinusitis. There was no significant difference in the diameter of the maxillary arteries in groups 1 and 2 . The study will be continued.

Research perspective. The results of this trial can be applied in maxilla-facial surgery for prognosis and treatment management of odontogenic maxillary sinusitis and may be proceeded for the better understanding of pathogenesis of chronic odontogenic maxillary sinusitis.

\section{References}

1. Kim JH, Ryu JS, Kim KD, Hwang SH, Moon HS. A radiographic study of the posterior superior alveolar artery. Implant Dent. 2011; 20(4): 306-310. doi: 10.1097/ID.0b013e31822634bd

2. Rahpeyma A, Khajehahmadi S. Alveolar antral artery: review of surgical techniques involving this anatomic structure. Iranian J of Otorhinolaryng. 2014; 26(75): 73-78. doi: 10.22038/IJORL.2014.2138

3. Pohodenko-Chudakova IO, Surin AV. Sravnitelnoe sopostavlenie mikrokristallizatsii biologicheskih sred u patsientov s hronicheskim odontogennyim sinusitom verhnechelyustnoy pazuhi [Comparative correlation of microcrystallization of biological media in patients with chronic odontogenic sinusitis of the maxillary sinus]. Novosti Khirurgii. 2013; 21(3): 79-83. [Russian] doi: 10.18484/2305-0047.2013.3.79

4. Ryan EL, Christopher ML, Todd AL, David MP. Odontogenic sinusitis: A review of the current literature. Laryngoscope Investig Otolaryngol. 2018; 3(2): 110-114. doi: 10.1002/lio2.147

5. Simuntis R, Kubilius R, Vaitkus S. Odontogenic maxillary sinusitis: a review. Stomatologija. 2014; 16(2): 39-43.

6. Soung Min Kim. Definition and management of odontogenic maxillary sinusitis. Maxillofac Plast Reconstr Surg. 2019; 41(1): 13. doi: 10.1186/s40902-019-0196-2

7. Zhartybaev RN, Smetov GG. Rannjaja diagnostika, lechenie i profilaktika odontogennogo verhnecheljustnogo sinusita $v$ stomatologicheskih ambulatornyh uslovijah (Literaturnyj obzor) [Early diagnosis, treatment and prevention of odontogenic maxillary sinusitis in dental outpatient basis (Literature review)]. Bull of KazNMU. 2016; 3: 86-90. [Russian]

8. Zirk M, Dreiseidler T, Pohl M, Rothamel D, Buller J, Peters F, et al. Odontogenic sinusitis maxillaris: A retrospective study of 121 cases with surgical intervention. J Craniomaxillofac Surg. 2017; 45: 520-525. doi: 10.1016/j. jcms.2017.01.023

9. Pohodenko-Chudakova IO, Chudakov OP, Zhavoronok SV, Barmutzkaya AZ, Kabanova SA, Kabanova AA, et al. Klinicheskoe rukovodstvo: diagnostika, prognozirovanie i lechenie tjazhelyh oslozhnenij infekcionno-vospalitel'nyh processov cheljustno-licevoj oblasti i shei [Clinical handbook: diagnosis, prognosis and treatment of severe complications of infectious and inflammatory processes of the maxillofacial area and neck]. Ed IO Pohodenko-Chudakova. Minsk: Publishing center of BSU; 2016. 398 p. [Russian]

10. Surin AV, Pohodenko-Chudakova IO. Informativnost integralnyih indeksov intoksikatsii u patsientov s hronicheskim odontogennyim sinusitom verhnechelyustnoy pazuhi [Informative value of integral indices of intoxication in patients with chronic odontogenic sinusitis of the maxillary sinus]. Ukr J of Med, Biology and Sports. 2018; 3-6 (15): 234-239. [Russian]. doi: 10.26693/jmbs03.06.234

11. WHO. Stomatologicheskoe obsledovanie: osnovnye metody. 5 izdanie [Dental examination: basic methods -5 th edition]. M: WHO; MSMSU by Al Evdokimov; 2013. 135 p. [Russian]

12. Kang SJ, Shin SI, Herr Y, Kwon YH, Kim GT, Chung JH. Anatomical structures in the maxillary sinus related to lateral sinus elevation: a cone beam computed tomographic analysis. Clin Oral Implants Res. 2013; 24: 75-81. doi: 10.1111/j.1600-0501.2011.02378.x

13. Testori T. Maxillary sinus surgery: anatomy and advanced diagnostic imaging. $J$ of Implant and Reconstruct Dent. 2011; 3(1): 18-25.

14. Shahbazian M, Vandewoude $C$, Wyatt J, Jacobs R. Comparative assessment of periapical radiography and CBCT imaging for radiodiagnostics in posterior maxilla. Odontology. 2015; 103: 97-104. doi: 10.1007/s10266013-0144-z

15. Toraman Alkurt M, Peker I, Degerli S, Cebeci AR, Sadik E. Comparison of cone-beam computed tomography and panoramic radiographs in detecting maxillary sinus septa. J Istanb Univ Fac Dent. 2016; 50: 8-14. doi: 10.17096/ jiufd.84476 
УДК 616.216.1-002.3-073.756.8

ВЕРИФІКАЦІЯ ВЕРХНЬОЩЕЛЕПНОÏ АРТЕРІї

ЗА ДАНИМИ КОНУСНО-ПРОМЕНЕВОЇ КОМП'ЮТЕРНОЇ ТОМОГРАФІЇ

У ПАЦІЄНТІВ 3 ХРОНІЧНИМ ВЕРХНЬОЩЕЛЕПНИМ СИНУСИТОМ

Походенько-Чудакова І. О., Максимович Є. В., Хоссейнпур А. М.

Резюме. Інфекційно-запальні захворювання верхньощелепного синуса займають значуще місце в структурі амбулаторного хірургічного стоматологічного прийому, і є однією з причин госпіталізації пацієнтів. Верхньощелепний синусит є одним з найбільш часто діагностованих запальних захворювань щелепно-лицевої ділянки. Слід зазначити, що цим захворюванням страждає 5-15\% дорослого працездатного населення (18-55 років), що робить дане питання значущим як в соціальному, так і в економічному плані. Конусно-променева комп'ютерна томографія $€$ основним діагностичним методом при обстеженні осіб даної категорії.

Мета дослідження - визначити візуалізацію, діаметр верхньощелепної артерії за даними конуснопроменевої комп'ютерної томографії стоматологічних пацієнтів, проаналізувати зв'язок з хронічним одонтогенним верхньощелепним синуситом.

Результати. Проаналізовано результати конусно-променевої комп'ютерної томографії (програма GALILEOS) 24 пацієнтів з хронічним одонтогенним верхньощелепним синуситом (група спостереження 1), та 20 пацієнтів без патологічних змін верхньощелепної пазухи (група порівняння 2) за період 2018-2020 рр. У результаті дослідження виявлено, що верхньощелепна артерія не визначалася в групі 1 у 25,0\% (12) пацієнтів, в групі 2 - у 5,0\% (2). У пацієнтів групи 1 діаметр артерії 0,1-0,99 мм визначався в 91,7\% (33) спостережень, у групи 2 - в 92,2\% (35). Діаметр верхньощелепної артерії 1,0 мм і більше у пацієнтів групи 1 визначався в 8,3\% (3) спостережень, у групи 2 - в 7,8\% (3). Виявлено різні типи локалізації верхньощелепної артерії. У результаті проведеного дослідження було встановлено, що у пацієнтів 1-ї групи з наявністю хронічного верхньощелепного синуситу верхньощелепна артерія візуалізувалася в 5 разів частіше, ніж у осіб 2-ї групи (групи порівняння), що може свідчити про більш глибокі ішемічні зміни в тканинах верхньої щелепи при хронічному верхньощелепному синуситі.

Ключові слова: конусно-променева комп'ютерна томографія, верхньощелепна артерія, хронічний верхньощелепний синусит.

УДК 616.216.1-002.3-073.756.8

ВЕРИФИКАЦИЯ ВЕРХНЕЧЕЛЮСТНОЙ АРТЕРИИ

ПО ДАННЫМ КОНУСНО-ЛУЧЕВОЙ КОМПЬЮТЕРНОЙ ТОМОГРАФИИ

У ПАЦИЕНТОВ С ХРОНИЧЕСКИМ ВЕРХНЕЧЕЛЮСТНЫМ СИНУСИТОМ

Походенько-Чудакова И. О., Максимович Е. В., Хоссейнпур А. М.

Введение. Инфекционно-воспалительные заболевания верхнечелюстного синуса занимают значимое место в структуре амбулаторного хирургического стоматологического приема, являются одной из причин госпитализации пациентов. Верхнечелюстной синусит является одним из наиболее часто диагностируемых воспалительных заболеваний челюстно-лицевой области. Следует отметить, что этим заболеванием страдает 5-15\% взрослого трудоспособного населения (18-55 лет), то делает данный вопрос значимым как в социальном, так и в экономическом плане. Конусно-лучевая компьютерная томография - основной диагностический метод при обследовании пациентов данной категории.

Цель исследования - определить визуализацию, диаметр верхнечелюстной артерии по данным конусно-лучевой компьютерной томографии стоматологических пациентов, проанализировать связь с хроническим одонтогенным верхнечелюстным синуситом. Проанализированы результаты конусно-лучевой компьютерной томографрии (программа GALILEOS) 24 пациентов с хроническим одонтогенным верхнечелюстным синуситом (группа наблюдения 1), 20 пациентов без патологических изменений верхнечелюстной пазухи (группа сравнения 2) за период 2018-2020 гг. В результате исследования выявлено, что верхнечелюстная артерия не определялась в группе 1 у $25,0 \%$ (12) пациентов, в группе 2 - у 5,0\% (2). У пациентов группы 1 диаметр артерии 0,1-0,99 мм определялся в 91,7\% (33) наблюдений, у группы 2 - в 92,2\% (35). Диаметр верхнечелюстной артерии 1,0 мм и более у пациентов группы 1 определялся в 8,3\% (3) наблюдений, у группы 2 - в 7,8\% (3). Выявлены разные типы локализации верхнечелюстной артерии. В результате проведенного исследования было установлено, что у пациентов 1-й группы с наличием хронического верхнечелюстного синусита верхнечелюстная артерия визуализировалась в 5 раз чаще, чем у лиц 2-й группы (группы сравнения), что может свидетельствовать о более глубоких ишемических изменениях в тканях верхней челюсти при хроническим верхнечелюстном синусите.

Ключевые слова: конусно-лучевая компьютерная томография, верхнечелюстная артерия, хронический верхнечелюстной синусит.

The authors of this study confirm that the research and publication of the results were not associated with any conflicts regarding commercial or financial relations, relations with organizations and/or individuals who may have been related to the study, and interrelations of coauthors of the article.

Стаття надійшла 28.09.2020 р.

Рекомендована до друку на засіданні редакційної коледії після рецензування 